The study suggests that promethazine is a potent stimulator or inducer of enzyme and protein synthesis and the benefit of promethazine in the treatment of Rh erythroblastosis may relate to enhancement of bilirubin disposal mechanisms.

\section{REFERENCES AND NOTES}

1. Berthelot, P., Erlinger, S., and Dhumeaux, D.: Phenobarbital enhancement of bile flow. Gastroenterology, 60:614 (1971).

2. Bierme-Alie-Enjalbert, S.: Les formes graves "in utero" de la maladie hemolitique perinatale par incompatibilite rhesus (Centre Regional de Transfusion Sanguine et d'Hematologie, Toulouse, 1967).

3. Catz, $C$, and Yaffe, S.: Barbiturate enhancement of bilirubin conjugation and excretion in young and adult animals. Pediat. Res., 2: 361 (1968).

4. Conney, A. H.: Pharmacological implications of microsomal enzyme induction. Pharmacol. Rev., 19: 317 (1967).

5. DeLeon, A., Gartner, L. M., and Arias, I. M.: The effect of phenobarbital on hyperbilirubinemia in glucuronyl transferase deficient rats. J. Lab. Clin. Med., 70: 273 (1967).

6. Gartner, L. M., and Arias, I. M.: Hormonal control of hepatic bilirubin transport and conjugation. Amer. J. Physiol., 222: 1091 (1972).

7. Gusdon, J. P., Moore, V. L., Myrvik, Q. N., and Holyfield, P. A.: Promethazine$\mathrm{HCl}$ as an immunosuppressant. Amer. J. Obstet. Gynecol., 108: 1340 (1972).

8. Gusdon, J. P., and Witherow, C.: Possible ameliorating effects of erythroblastosis by promethazine hydrochloride. Amer. J. Obstet. Gynecol., 117: 101 (1973).

9. Levi, A J., Gatmaitan, Z., and Arias, I. M.: Deficiency of hepatic anion binding and jaundice in newborn monkeys. N. Eng. J. Med., 283: 1136 (1970).

10. Lowry, O. H., Rosebrough, N. J., Farr, A. L., and Randall, R. J.: Protein measurement with the Folin phenol reagent. J. Biol. Chem. 193: 265 (1951).

11. McMullin, G. P., Hayes, M. F., and Arora, S. C.: Phenobarbitone in rhesus haemolytic disease Lancet, ii: 949 (1970).

12. Redinger, R. N., and Small, D. M.: Primate biliary physiology. VIII. The effect of phenobarbital upon bile salt synthesis and pool size, biliary secretion and bile composition. J. Clin. Invest., 52: 161 (1973).

13. Reyes, H., Levi, A. J., Gatmaitan, Z., and Arias, I. M.: Organic anion-binding protein in rat liver: Drug induction and its physiologic consequence. Proc. Nat. Acad. Sci. U. S. A., 64: 168 (1969).

14. Reyes, H., Levi, A. J., Gatmaitan, Z and Arias, I. M.: Studies of $Y$ and Z, two hepatic cytoplasmic organic anion-binding proteins: Effect of drugs, chemicals, hormones and cholestasis. J. Clin. Invest., 50: 2242 (1971).

15. Roberts, R. J., and Plaa, G. L.: Effect of phenobarbital and the excretion of an exogenous bilirubin load. Biochem. Pharmacol., 16: 827 (1967).

16. Rubinestein, A., Eidelman, A. I., Melamed, J., Gartner, L. M., and Kandall, S: Possible effect of maternal promethazine therapy on neonatal immunologic functions. J. Pediat., 89: 136 (1976).

17. Rubinstein, A. Schulman, H., and Eidelman, A. I.: Promethazine immunosuppression of Rh erythroblastosis. Pediat. Res., 9: 326 (1975).

18. Runyòn, R. P., and Haber, A.: Fundamentals of Behavioral Statistics (AddisonWesley Publishing Co., Reading, Mass., 1967).

19. This work was supported by grants from the National Institute for Child Health and Human Development (5R01-HD03783), NIH International Fellowship Award (3F05 TW01850-0140151), the Gail Zuckerman Foundation for Research in Chronic Liver Diseases of Children, and Liver Research Center of the Albert Einstein College of Medicine.

20. Dr. S. L. Vaisman was a recipient of National Institutes of Health International Fellowship.

21. Dr. L. M. Gartner is Research Career Development Awardee, National Institute for Child Health and Development.

22. Requests for reprints should be addressed to: L. M. Gartner, M. D., Department of Pediatrics, Albert Einstein College of Medicine, 1300 Morris Park Ave., Bronx, N. Y. 10461 (USA).

23. Accepted for publication April 1, 1976.
ABO incompatibility, Rhesus incomparibility antibody-dependent cytotoxicity, cell-mediated erythrocytes fetus hemolysis leukocytes

\title{
Antibody-dependent Cell-mediated Destruction of Human Erythrocytes Sensitized in ABO and Rhesus Fetal-Maternal Incompatibilities
}

\author{
S. A. ZAWODNIK, ${ }^{(27)}$ G. D. BONNARD, AND E. GAUTIER \\ Immunogentic Laboratory, Department of Pediatrics, Hôpital Cantonal Universitaire, Lausanne, Switzerland
}

\author{
H. R. MACDONALD
}

Department of Immunology, Swiss Institute for Experimental Cancer Research, Lausanne, Switzerland

\section{Extract}

Antibody-dependent cell-mediated cytotoxicity (ADCMC) was measured in a ${ }^{51} \mathrm{Cr}$-release assay with antibody-sensitized human red blood cells (RBC) as target cells and nonimmune isologous or autologous mononuclear peripheral blood leukocytes (MPBL) as effector cells. ADCMC was readily demonstrable within $6 \mathrm{hr}$ and was independent of exogenous complement $\left(C^{\prime}\right)$. The specificity of the $A D C M C$ reaction was determined by the antiserum employed. Anti-A, anti-B, anti-D, and anti-c sera were all active in ADCMC; the specific lysis was between 35 and $50 \%$ with antiserum dilution of $1 / 1,000$, using $10^{5}$ target cells and $10^{6} \mathrm{MPBL}$. Anti-C, anti-E, and anti-e sera had no detectable activity. Sephadex column separation suggested that this activity was by antibodies of the IgG class.
Cord RBC from infants with $\mathrm{RhD}$ fetal-maternal incompatibility were lysed by autologous or isologous MPBL in the absence of exogenous antiserum. ADCMC was between $22 \%$ and $42 \%$ in.cases with high direct Coombs' test, but was negative with low direct Coombs' test as in five cases of $\mathrm{ABO}$ incompatibility.

\section{Speculation}

In hemolytic disease of the newborn, the precise mechanisms involved in the destruction of fetal erythrocytes sensitized with maternal antibodies are not well known. The experiments described in this report raise the possibility that ADCMC could be operative in vivo 
The precise events leading to the destruction of fetal erythrocytes in hemolytic disease of the newborn are not known. There is evidence that fetal erythrocytes coated with maternal IgG antibodies can be lysed by cell-mediated mechanisms (3-5). In this context, the potential interactions between mononuclear cells, red cells, and IgG in man have been extensively investigated (1, 2, 10-12). Recent results by Holm and his colleagues (7-9) have demonstrated ADCMC against human RBC pretreated with isologous antisera to blood group antigens, mediated by nonimmune human MPBL. Using erythrocytes as target cells, the effector population for ADCMC among mononuclear cells appears to be monocytes. Antibody-dependent cytotoxic lymphoid cells ( $\mathrm{K}$ cells) are not efficient killers of human erythrocytes, although they are extremely active against sensitized nucleated target cells $(13,15)$.

In this paper we report a study of ADCMC in fetal-maternal incompatibilities.

\section{MATERIALS AND METHODS}

\section{MEDIUM}

The medium used throughout this study was Dulbecco's modified Eagle's medium (16) supplemented with $5 \%$ heat-inactivated $\left(56^{\circ}\right.$ for $\left.45 \mathrm{~min}\right)$ fetal calf serum, penicillin, streptomycin, and bicarbonate as buffer.

\section{TARGET CELLS}

Fresh human $\mathrm{RBC}$ in $\mathrm{ACD}$ were genotyped for $\mathrm{ABO}$ and $\mathrm{Rh}$ antigens (17). After two washings in Hanks' balanced salt solution, $20-30 \times 10^{6} \mathrm{RBC}$ in $0.2 \mathrm{ml}$ buffer $(0.8 \mathrm{~g} \mathrm{NaCl}, 0.038 \mathrm{~g} \mathrm{KCl}, 0.01$ $\mathrm{Na}_{2} \mathrm{PO}_{4}$, and $0.3 \mathrm{~g}$ Tris, $100 \mathrm{ml}$, adjusted to $\mathrm{pH} 7.40$ with $\mathrm{HCl}$ ) were labeled for $30 \mathrm{~min}$ with $200 \mu \mathrm{Ci}{ }^{51} \mathrm{Cr}\left(\mathrm{Na}_{2} \mathrm{CrO}_{4}, 1 \mathrm{mCi} / \mathrm{ml}\right.$, specific activity $200 \mu \mathrm{Ci} / \mathrm{mg} \mathrm{Cr}$ or more) (18). The target cells were then washed twice with Hanks' solution and resuspended in medium at a concentration of $0.5 \times 10^{6} / \mathrm{ml}$.

When $\mathrm{RBC}$ from cord blood were used as target cells, they were washed four times with $0.9 \mathrm{M} \mathrm{NaCl}$ at $37^{\circ}$ and then once in Hanks' solution before labeling with ${ }^{51} \mathrm{Cr}$.

\section{ANTISERA}

Antisera to $R h$ System. Both maternal and commercially available human hyperimmune antisera were used. The commercial preprations included: anti-D serum (DADE (19) catalog no. B 4665, lot D-616 EC and D-625 GW), anti-c serum (DADE (19) catalog no. B 4695), anti-C serum (DADE (19) catalog no. B 4685), anti-e serum (DADE (19) catalog no. B 4716) and anti-E serum (DADE (19) catalog no. B 4705). These antisera had no $C^{\prime}-$ dependent lytic activity. All antisera were inactivated by heating at $56^{\circ}$ for $45 \mathrm{~min}$. Anti-D sera had hemagglutination titers (indirect Coombs' test) of 1:524,288 or more. One lot (D-616 EC) contained $6.3 \mathrm{IU} / \mathrm{ml} \mathrm{IgG}$ and $12.0 \mathrm{IU} / \mathrm{ml} \mathrm{IgM}$, measured by a radial diffusion technique $(6,14)$.

Anti-A and Anti-B Sera. Both maternal and commercially available human hyperimmune antisera were used. Commercial preparations came from DADE (19): anti-A serum (catalog no. B 4627-1, lot A-478 XX), anti-B serum (catalog no. B 4627-2, lot B-590 WY). These antisera had C-dependent hemolytic activity for $\mathrm{RBC}$ of the relevant blood group but not after inactivation at $56^{\circ}$ for $45^{\circ} \mathrm{min}$. The hemagglutination titer of each antiserum was greater than $1: 524,288$.

\section{EFFECTOR CELLS}

Human MPBL of group $\mathrm{O} \mathrm{Rh}^{-}$donors were separated from heparinized whole blood by Ficoll-Isopaque gradient centrifugation $\left(d=1.077,650 \times g, 20 \mathrm{~min}, 20^{\circ}\right)$. The white cell layer at the interface was collected, washed twice in $\mathrm{Ca}^{++}$and $\mathrm{Mg}^{++}$-free
Hanks' solution, and centrifuged at $150 \times g$ to remove thrombocytes. After erythrocyte lysis by incubation for $5 \mathrm{~min}$ in $0.88 \%$ $\mathrm{NH}_{4} \mathrm{Cl}$ in Tris buffer, $\mathrm{pH} 7.6$, the cells were washed in Hanks' solution and resuspended in medium at $2 \times 10^{6}$ cells $/ \mathrm{ml}$. Differential counts of cells on cytocentrifuge smears stained with May-Grünwald Giemsa revealed that the MPBL effector cell population consisted of approximately $80-85 \%$ lymphocytes, $15-20 \%$ monocytes, and $0-3 \%$ polymorphonuclear leukocytes. More than $95 \%$ of the cells were viable as assessed by trypan blue dye $(0.05 \%)$ exclusion Cord blood MPBL were prepared by the same procedure.

\section{CYTOTOXICITY ASSAY}

The following standard experimental conditions were used for ADCMC tests, unless otherwise stated. The effector cells $\left(10^{6}\right.$ in $0.5 \mathrm{ml})$ were mixed with ${ }^{51} \mathrm{Cr}$-labeled target cells $\left(10^{5}\right.$ in $\left.0.2 \mathrm{ml}\right)$ and then the heat-inactivated antiserum to these target cells $(0.2 \mathrm{ml}$ of various dilutions) was added. The mixtures were placed in conical plastic tubes, $10 \times 64 \mathrm{~mm}(20)$, and supplemented with 0.1 $\mathrm{ml}$ medium to a total volume of $1 \mathrm{ml}$. Controls without added antiserum were included in all experiments. All assays were carried out in duplicate. The reaction mixtures were incubated for $20 \mathrm{hr}$. After incubation, $1 \mathrm{ml}$ cold phosphate-buffered saline was added, tubes were centrifuged at $365 \times g$ for $1 \mathrm{~min}$, and $1 \mathrm{ml}$ supernatant was carefully removed. Then the radioactivity of the supernatant was counted in a well type $\gamma$ counter (21). The results were expressed as percentage of specific lysis as calculated by the following formula

$$
\% \text { Specific lysis }=\frac{\text { Experimental }^{{ }^{5} 1} \mathrm{Cr} \text { release }- \text { spontaneous }}{{ }^{{ }^{5} 1} \mathrm{Cr} \text { release }}
$$

Maximal ${ }^{51} \mathrm{Cr}$ release was determined by acetic acid lysis of target cells. Spontaneous ${ }^{51} \mathrm{Cr}$ release was $4 \%$ or less in all experiments. Cytotoxicity results are expressed as means of duplicates, within which variations rarely exceeded $\pm 2.5 \%$.

\section{ANTIBODY-DEPENDENT C'-MEDIATED LYSIS}

Fresh, noninactivated immune maternal antiserum at various dilutions was added $(0.2 \mathrm{ml})$ to appropriate ${ }^{51} \mathrm{Cr}$-labeled $\mathrm{A}, \mathrm{B}$, or $\mathrm{RhD} \mathrm{RBC}\left(0.2 \mathrm{ml}\right.$ containing $10^{5}$ cells $)$ in conical plastic tubes, and the mixtures were made up to $1 \mathrm{ml}$ with medium. After $20 \mathrm{hr}$ of incubation $C^{\prime}$-mediated lysis was assessed in the manner described above.

\section{RESULTS}

\section{SPECIFICITY OF ADCMC TO RhD AND A AND B ANTIGENS}

In order to investigate specificity, ADCMC experiments were performed using the commercial preparations of human hyperimmune anti-A, anti-B, and anti-D sera. When $10^{5} \mathrm{O}$ RhD RBC as target cells were mixed with appropriate concentrations of heatinactivated anti-D serum and with $10^{6} \mathrm{MPBL}$ as effector cells, lysis was readily demonstrable after $20 \mathrm{hr}$ of incubation (Fig. $1 \mathrm{~A}$ ). This lysis was specific for $\mathrm{RhD}$ cells, since $\mathrm{Rh}-\mathrm{RBC}$ were not lysed under comparable conditions. The absence of lysis of $\mathrm{Rh}-$ cells was not due to a technical failure, since $A \mathrm{Rh}-\mathrm{RBC}$ were lysed in the presence of anti-A serum (Fig. 1B).

When heat-inactivated anti-A and anti-B sera were compared for their ability to induce ADCMC of human RBC of different blood group types, lysis was observed only when the labeled RBC carried the appropriate antigens (Fig. 1B).

These experiments, all of which were repeated several times using the same antiserum, demonstrated that the specificity of ADCMC was determined by the specificity of the antiserum. 


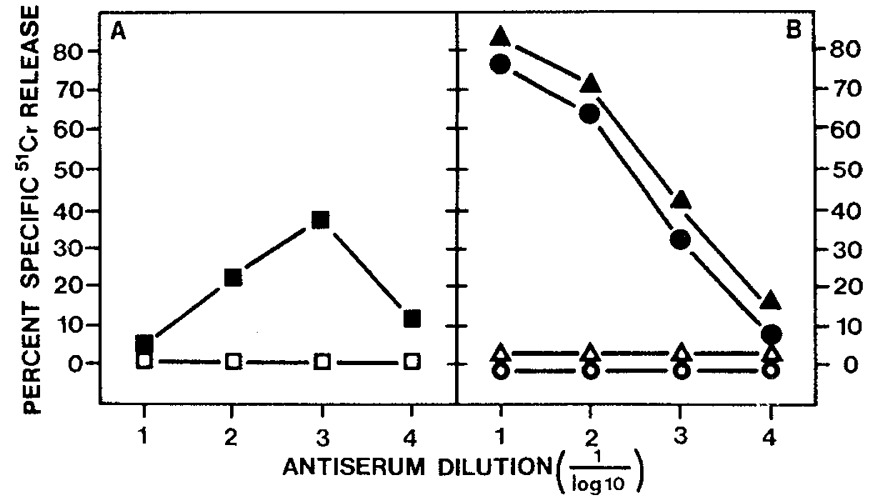

Fig. 1. Antibody-dependent, cell-mediated cytotoxicity induced by antisera against blood group antigens. Specific ${ }^{52} \mathrm{Cr}$ release estimated under standard experimental conditions, using various dilutions of the antisera. $A: \mathbf{\square}$, anti-D serum with $\mathrm{O}$ RhD target cells; $\square$, anti-D serum with $\mathrm{A} \mathrm{Rh}-$ or B Rh - target cells. B: $\mathbf{A}$, anti-A serum with $\mathrm{A} \mathrm{Rh}$ - target cells; $\triangle$, anti-A serum with $\mathrm{B} R \mathrm{Rh}-$ target cells; $\bullet$, anti-B serum with $\mathrm{B}$ $\mathrm{Rh}$ - target cells; $\mathrm{O}$, anti-B serum with $\mathrm{A} \mathrm{Rh}$ - target cells. Mononuclear peripheral blood leukocytes alone or any of the antisera alone did not induce significant specific lysis. The results shown are those of a single representative experiment.

Table 1. Antibody-dependent, cell-mediated cytotoxicity $(A D C M C)$ of human erythrocytes using various antisera within rhesus system

\begin{tabular}{lrccc}
\hline \multirow{2}{*}{$\begin{array}{c}\text { Antiserum } \\
\text { used, } 1 / 1,000 \\
\text { dilution }\end{array}$} & \multicolumn{4}{c}{$\begin{array}{c}\text { \% ADCMC on target R BC with } \\
\text { following phenotypes }\end{array}$} \\
\cline { 2 - 5 } & ccddee & CcDee & CCDee & ccDEE \\
\hline Anti-c & 41 & 4 & 0 & 7 \\
Anti-C & 0 & 0 & 2 & 0 \\
Anti-D & 0 & 17 & 15 & 28 \\
Anti-e & 0 & 0 & 0 & 0 \\
Anti-E & 0 & 0 & 0 & 0 \\
\hline
\end{tabular}

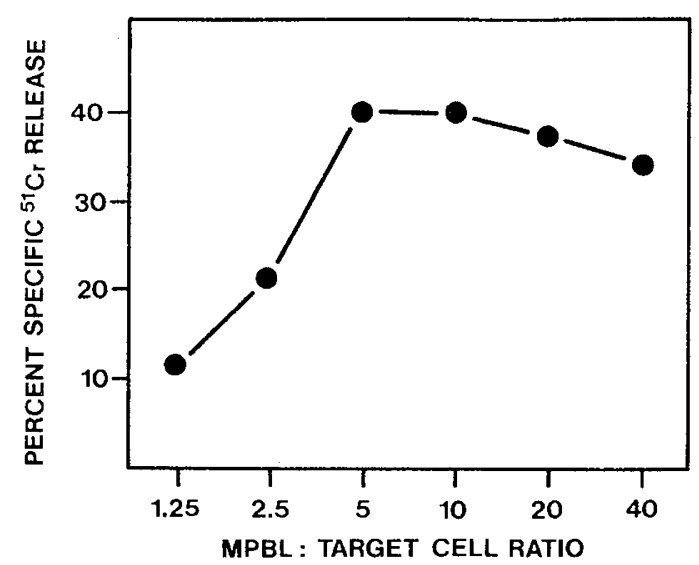

Fig. 2. Dependence of Antibody-dependent, cell-mediated cytotoxicity on the number of effector cells. Increasing numbers of mononuclear peripheral blood leukocytes $(M P B L)$ were incubated with $10^{5} \mathrm{RhD}$ target cells, sensitized with anti-D serum $(1 / 1,000)$.

\section{ADCMC INDUCED BY ANTIBODIES TO OTHER Rh ANTIGENS}

Various labeled RBC were incubated with MPBL and a $1 / 1,000$ dilution of commercial anti-c, anti-C, anti-D, anti-e, and anti-E sera (Table 1). Definite lysis of homozygous $\mathrm{Rh}-\mathrm{cc} \mathrm{RBC}$ was achieved using the anti-c serum, whereas heterozygous $\mathrm{RhDCc}$
RBC were lysed very weakly. Anti-C, anti-e, and anti-E sera induced no or very little lysis. Control RhD RBC were lysed with anti-D serum. No evidence for nonspecific lysis was obtained in these experiments, which were performed three times with similar results.

\section{CONDITIONS FOR ADCMC USING ANTI-D SERUM}

Lysis was related to MPBL number in the range of $0.125-0.5 \times$ $10^{6}$ cells (MPBL: $\mathrm{RBC}$ ratio $1.25-5$ ), but reached a plateau in the range of $0.5-4 \times 10^{6}$ cells (MPBL: RBC ratio 5-40) (Fig. 2). Similar levels of lysis (15-39\%) were observed in nine other experiments.

Almost $90 \%$ of the final specific lysis was achieved in the first 6 hr of incubation (Fig. 3).

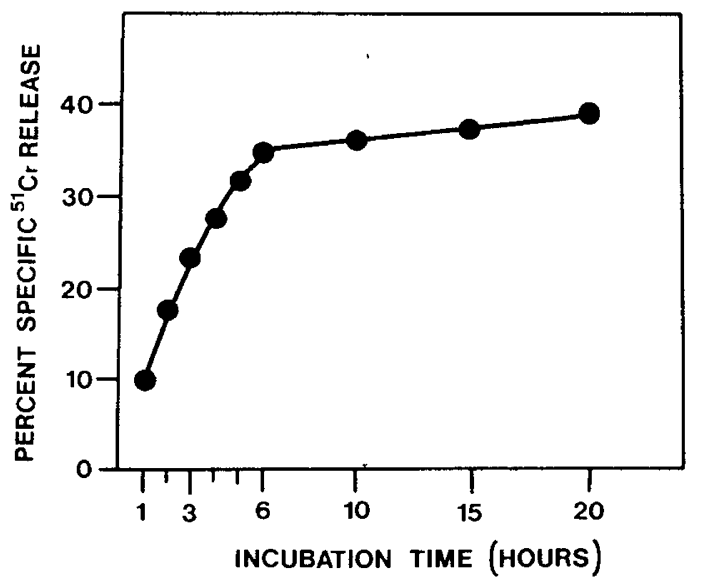

Fig. 3. The effect of time of incubation on antibody-dependent, cell-mediated cytotoxicity. Cultures were of $10^{6}$ mononuclear peripheral blood leukocytes added to $10^{5} \mathrm{RhD}$ erythrocytes, sensitized with anti-D serum $(1 / 1,000)$.

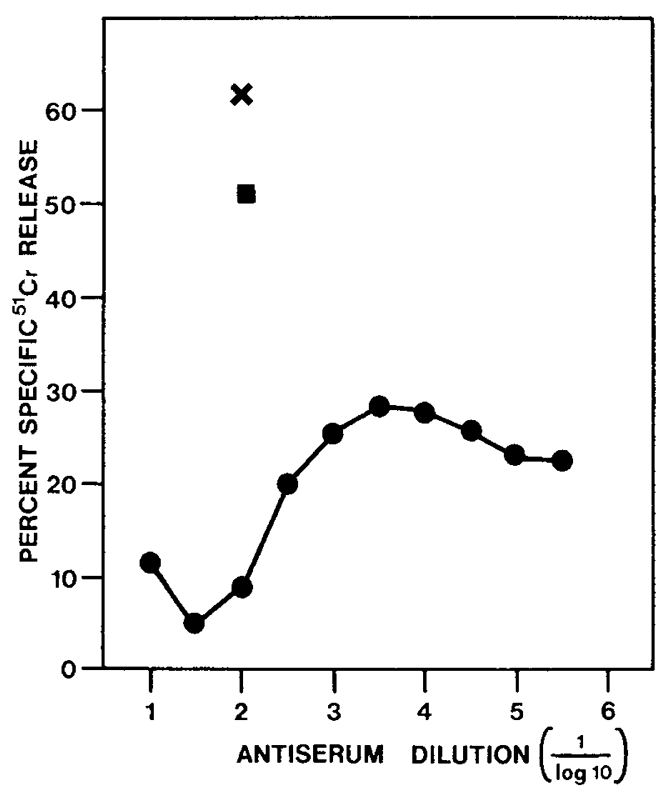

Fig. 4. Inhibition of antibody-dependent, cell-mediated cytotoxicity by high concentrations of anti-D serum. - standard experimental conditions. Target cells: $10^{5} \mathrm{O}$ RhD RBC. Effector cells: $10^{6}$ mononuclear peripheral blood leukocytes. Commercial anti-D serum at the indicated dilution; $x$, pretreatment procedure: target cells incubated for $30 \mathrm{~min}$ with a $1 / 1,000$ dilution of antiserum and then washed twice before the $20 \mathrm{hr}$ of incubation; 口, specific lysis obtained with anti-D serum (1/1,000 dilution), ultracentrifuged at $10000 \times g$ for 4 hours. 
ADCMC was inhibited in the presence of high concentrations of anti-D serum (see examples in Fig. $1 A$ and Fig. 4). This inhibition may be due to immunoglobulin aggregates in the antiserum. When target cells were incubated for $30 \mathrm{~min}$ with anti-D serum and washed twice before the addition of the effecor cells, more lysis was observed (Fig. 4). Increased lysis was also observed when an aliquot of the anti-D serum was ultracentrifuged before use (Fig. 4).

Table 2. Assay of ability of Sephadex G-200 immunoglobulin fractions of commercial anti-D serum to induce antibody-dependent, cell-mediated cytotoxicity $(A D C M C)$ of human RhD erythrocytes ${ }^{1}$

\begin{tabular}{lccccc}
\hline \multirow{2}{*}{ Fraction } & \multicolumn{5}{c}{$\%$ ADCMC at dilution } \\
\cline { 2 - 6 } & $1 / 10$ & $1 / 100$ & $1 / 1,000$ & $1 / 10,000$ & $1 / 100,000$ \\
\hline $\begin{array}{l}\text { Whole } \\
\text { serum }\end{array}$ & 0 & 13 & 27 & 20 & 5 \\
IgM & 0 & 0 & 0 & n.d. $^{1}$ & n.d. \\
IgG & 2 & 12 & 9 & 3 & 1 \\
\hline
\end{tabular}

'n.d.: not determined.

Table 3. Comparison of activity of maternal isoimmune sera in indirect Coombs' test and induction of antibody-dependent, cell-mediated cytotoxicity $(A D C M C)$

\begin{tabular}{|c|c|c|c|}
\hline \multirow{2}{*}{ Case } & \multirow{2}{*}{$\begin{array}{l}\text { Type of } \\
\text { isoimmun- } \\
\text { ization }\end{array}$} & \multicolumn{2}{|c|}{ Maternal serum } \\
\hline & & $\begin{array}{c}\text { Indirect } \\
\text { Coombs' titer }\end{array}$ & $\% \mathrm{ADCMC}^{1}$ \\
\hline$I$ & RhD & $1 / 256$ & $28.4(1 / 1,000)$ \\
\hline 2 & RhD & $1 / 256$ & $31.2(1 / 1,000)$ \\
\hline 3 & RhD & $1 / 16,384$ & $26.1(1 / 1,000)$ \\
\hline 4 & $\mathrm{RhD}$ & $1 / 16,384$ & $25.9(1 / 1,000)$ \\
\hline 5 & RhD & $1 / 16,384$ & $33.8(1 / 1,000)$ \\
\hline 6 & $\mathrm{RhD}$ & $1 / 16,384$ & $40.9(1 / 1,000)$ \\
\hline 7 & RhD & $1 / 32,768$ & $38.1(1 / 1,000)$ \\
\hline 8 & RhD & $1 / 65,536$ & $38.6(1 / 1,000)$ \\
\hline 9 & RhD & $1 / 262,144$ & $41.0(1 / 1,000)$ \\
\hline 10 & Rr.D & $1 / 524,288$ & $42.2(1 / 1,000)$ \\
\hline 11 & $\mathrm{OA}$ & $1 / 1,024$ & $61.1(1 / 100)$ \\
\hline 12 & $\mathrm{OA}$ & $1 / 1,024$ & $68.1(1 / 10)$ \\
\hline 13 & $\mathrm{OA}$ & $1 / 2,048$ & $68.3(1 / 10)$ \\
\hline 14 & $\mathrm{OB}$ & $1 / 2,048$ & $58.4(1 / 100)$ \\
\hline 15 & $\mathrm{OB}$ & $1 / 1,024$ & $71.1(1 / 10)$ \\
\hline
\end{tabular}

${ }^{1}$ Heat-inactivated maternal immune sera on adult red blood cells under standard experimental conditions. The antiserum dilution at which maximal lysis occurred is indicated in parentheses.
Commerical anti-D serum was separated on a Sephadex G-200 column into IgG and IgM fractions. No lysis was seen with the IgM fraction under standard experimental conditions. The IgG fraction did induce lysis, but less strongly than whole serum (Table 2).

\section{ADCMC AND C'-MEDIATED LYSIS BY MATERNAL IMMUNE SERA}

$A D C M C$ was induced by 10 sera from mothers with $R$ hD isoimmunization and in all instances was similar to that induced by commercial anti-D sera (Table 3). Maternal sera from three cases of $\mathrm{OA}$ and from two cases of $\mathrm{OB}$ isoimmunizations also induced ADCMC (Table 3). No correlation was found between the titer in the indirect Coombs' test and the percentage of lysis in ADCMC.

Direct $\left(C^{\prime}\right.$-mediated) lysis was observed when $A$ or $B$ group $R B C$ were incubated for $20 \mathrm{hr}$ with maternal noninactivated immune anti-A or anti-B serum at dilutions of $1 / 10$ or $1 / 100$. On the other hand, no hemolysis of RhD RBC occurred with maternal noninactivated immune anti-D serum. In all controls using heat-inactivated maternal anti-A, anti-B, and anti-D sera no direct lysis occurred. Usually, ADCMC was detectable using heat-inactivated serum at one or two doubling dilutions beyond the $C^{\prime}$-mediated hemolytic concentrations for noninactivated serum (Table 4).

\section{ADCMC OF NEWBORN RBC SENSITIZED IN VIVO}

Cord RBC were collected from infants with fetal-maternal blood group incompatibilities. After washing, the cells were labeled and used as target cells. It was found that cells from RhD incompatibility were often lysed by MPBL from normal donors without addition of any further immune serum (Table 5, Direct ADCMC). From Table 5 it can also be seen that there was some correlation between the degree of lysis observed by direct ADCMC and the titer obtained in the direct Coombs' test. The two cases with the lowest Coombs' titers did not show lysis by the direct ADCMC technique. As a group the children who required two exchange transfusions had a higher percentage of lysis than the others.

No direct ADCMC was observed in the five cases of $\mathrm{ABO}$ incompatibilities. Their direct Coombs' titers were between $1 / 16$ and $1 / 64$.

Nevertheless, in all instances the heat-inactivated maternal sera induced ADCMC of the corresponding newborn target $\mathrm{RBC}$, the amount of lysis (data not shown) being similar to that on adult RBC (Table 3).

\section{AUTOLOGOUS MONOCYTES FROM NEWBORNS AS EFFECTOR CELLS IN ADCMC}

RhD-sensitized cord blood RBC from case 4, with direct Coombs' titer of $1 / 4096$, were lysed by autologous MPBL used at three concentrations. Comparable lysis was obtained with unrelated donor's MPBL (Fig. 5). Three other ADCMC tests, in which autologous and isologous effect cells were compared, are shown in Table 5.

Table 4. Comparison of complement $\left(C^{\prime}\right)$-mediated and cell-mediated lysis induced by maternal isoimmune sera from three cases of fetal-maternal incompatibility

\begin{tabular}{|c|c|c|c|c|c|c|c|c|}
\hline \multirow{3}{*}{$\begin{array}{l}\text { Fetal-maternal } \\
\text { incompatibility }\end{array}$} & \multicolumn{4}{|c|}{$\%$ Specific antibody-dependent $C^{\prime}$-mediated lysis ${ }^{1}$} & \multicolumn{4}{|c|}{$\%$ Specific ADCMC ${ }^{2}$} \\
\hline & \multicolumn{4}{|c|}{ Antiserum dilution } & \multicolumn{4}{|c|}{ Antiserum dilution } \\
\hline & $1 / 10$ & $1 / 100$ & $1 / 1,000$ & $1 / 10,000$ & $1 / 10$ & $1 / 100$ & $1 / 1,000$ & $1 / 10,000$ \\
\hline $\mathrm{OA}$ & 72.1 & 68.4 & 0 & 0 & 68.3 & 65.5 & 38.1 & 24.7 \\
\hline OB & 69.2 & 61.3 & 0 & 0 & 71.1 & 63.9 & 41.4 & 26.4 \\
\hline $\mathrm{RhD}$ & 0 & 0 & 0 & 0 & 7.7 & 17.1 & 33.4 & 14.8 \\
\hline
\end{tabular}

${ }^{1}$ Noninactivated maternal immune antiserum.

${ }^{2}$ ADCMC: antibody-dependent, cell-mediated cytotoxicity. Heat-inactivated maternal immune antiserum. 
Table 5. Susceptibility of newborn red blood cells to direct antibody-dependent, cell-mediated cytotoxicity $(A D C M C)$

\begin{tabular}{|c|c|c|c|c|}
\hline Case & $\begin{array}{l}\text { Type of } \\
\text { isoimmun- } \\
\text { ization }\end{array}$ & $\begin{array}{l}\text { No. of } \\
\text { exchange } \\
\text { trans- } \\
\text { fusions }\end{array}$ & $\begin{array}{l}\text { Direct } \\
\text { Coombs' } \\
\text { titer }\end{array}$ & $\begin{array}{l}\% \text { Direct } \\
\text { ADCMC }\end{array}$ \\
\hline 1 & $\mathrm{RhD}$ & 0 & $1 / 16$ & 0 \\
\hline 2 & $\mathrm{RhD}$ & 1 & $1 / 64$ & 0 \\
\hline 3 & $R h D$ & 1 & $1 / 4,096$ & 22.2 \\
\hline 4 & $\mathrm{RhD}$ & 1 & $1 / 4,096$ & $25.0^{1}$ \\
\hline 5 & $\mathrm{RhD}$ & 1 & $1 / 4,096$ & $26.0^{1}$ \\
\hline 6 & RhD & 2 & $1 / 8,192$ & 39.6 \\
\hline 7 & $\mathrm{RhD}$ & 2 & $1 / 8,192$ & 38.7 \\
\hline 8 & RhD & 1 & $1 / 16,384$ & $42.2^{1}$ \\
\hline 9 & $\mathrm{RhD}$ & 2 & $1 / 131,072$ & 37.5 \\
\hline 10 & RhD & 2 & $1 / 524,288$ & $37.1^{1}$ \\
\hline 11 & $\mathrm{OA}$ & 1 & $1 / 32$ & 0 \\
\hline 12 & $\mathrm{OA}$ & 0 & $1 / 32$ & 0 \\
\hline 13 & $\mathrm{OA}$ & 1 & $1 / 64$ & 0 \\
\hline 14 & $\mathrm{OB}$ & 0 & $1 / 16$ & 0 \\
\hline 15 & $\mathrm{OB}$ & 0 & $1 / 32$ & 0 \\
\hline
\end{tabular}

${ }^{1}$ Data given for autologous effector cells only.

Table 6. Dependence of autologous antibody-dependent, cell-mediated cytotoxicity $(A D C M C)$ on presence of phagocytic mononuclear peripheral blood leukocytes (MPBL)

\begin{tabular}{lrrrrrr}
\hline \multirow{7}{*}{$\begin{array}{c}\text { Treatment of } \\
\text { MPBL }\end{array}$} & \multicolumn{6}{c}{ \% Specific ${ }^{51}$ Cr release } \\
\cline { 2 - 7 } & $40: 1^{1}$ & $20: 1$ & $10: 1$ & $5: 1$ & $2.5: 1$ & $1.25: 1$ \\
\hline None $^{2}$ & 32.2 & 39.4 & 33.4 & 27.5 & 9.1 & 5.0 \\
Carbonyl iron $^{3}$ & 1.3 & 4.8 & 4.4 & 2.8 & 2.7 & 2.7 \\
\hline
\end{tabular}

${ }^{1}$ MPBL to target cell ratio.

${ }^{2}$ Differential white cell count; $15-20 \%$ monocyte content.

${ }^{3}$ Differential white cell count; $2-3 \%$ monocyte content.

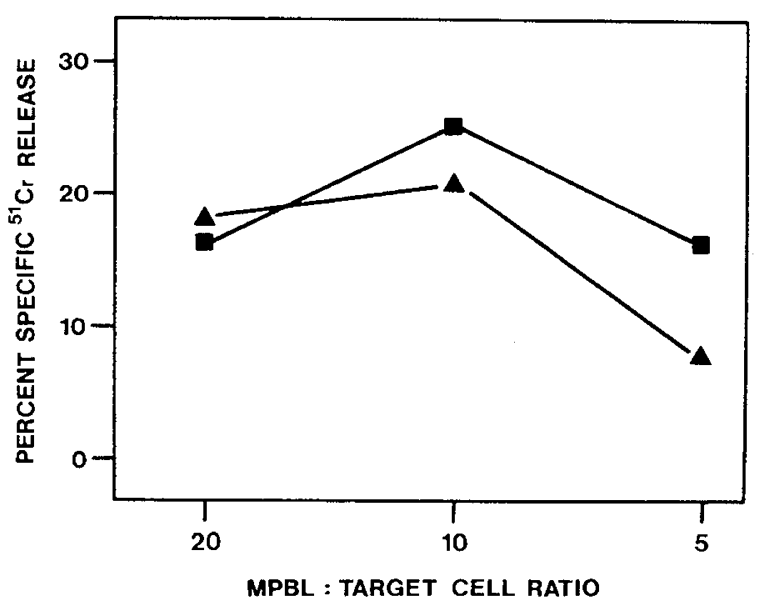

Fig. 5. Specific antibody-dependent, cell-mediated cytotoxicity induced by autologous and isologous effector cells on O RhD RBC sensitized in vivo. Target cells were $10^{5}$ in vivo sensitized cord blood O RhD RBC. Mononuclear peripheral blood leukocytes were added at the ratios shown. $\boldsymbol{\Lambda}$, unrelated donor O RhD MPBL; $\mathbf{E}$, autologous MPBL.

Monocytes were removed from a newborn MPBL suspension (case 8 of RhD fetal-maternal incompatibility) by the carbonyl iron technique (13). ADCMC activity against cord blood RBC (sensitized in vivo) was strongly reduced by this procedure, suggesting that monocytes were the main effector cells in this ADCMC system (Table 6).

\section{DISCUSSION}

Our results show that nonimmune MPBL specifically lyse ${ }^{51} \mathrm{Cr}$-labeled human erythrocytes sensitized in vitro or in vivo with antibodies directed against blood group antigens. In addition to $\mathrm{ABO}$ and $\mathrm{RhD}$ specificities, an antiserum against the rhesus phenotype $\mathrm{cc}$ also induced lysis of $\mathrm{RBC}$ of this phenotype. However, antisera to $\mathrm{Cc}, \mathrm{CC}$, ee, and $\mathrm{EE}$ induced little or no lysis of target cells bearing these antigens.

Isologous and autologous monocytes were found to act as effector cells for both in vitro and in vivo sensitized RBC. After separation of a commercial anti-D serum on a Sephadex column, only the IgG fraction was found to have appreciable ADCMC activity, in agreement with other studies (8). In all cases specificity of lysis corresponded to the specificity of the isoantiserum employed.

Most release of ${ }^{51} \mathrm{Cr}$ occurred during the first few hours of incubation with MPBL. Assessment of lysis at various MPBL to target cell ratios further suggested that the effector cells were quite efficient, since appreciable ${ }^{5} \mathrm{Cr}$ release was detected at ratios of about $1: 1$. In the absence of granulocytes, monocytes are the effector cells in this system (Table 6) $(8,9,13)$. It is possible that actual effector to target cell ratios are of the order of $0.1-0.2: 1$. Our studies do not, however, exclude the possibility that granulocytes may also kill sensitized human erythrocytes $(13,15)$.

We also studied ADCMC in cases of fetal-maternal incompatibility. The mechanism of hemolysis in this situation is still unclear. In $O A$ and $O B$ incompatibility, antibodies are found which can induce $C^{\prime}$-mediated lysis. The antibodies of $\mathrm{Rh}$ incompatibility, however, do not induce this lysis mechanism in vitro. Thus cell-mediated mechanisms may be more important in $\mathrm{Rh}$ hemolytic disease $(1-4,11)$.

The following observations are compatible with the possibility that ADCMC could operate in vivo. (l) Monocyte-mediated ADCMC of presensitized RBC can be obtained with immune sera against the specificities $\mathrm{A}, \mathrm{B}, \mathrm{RhD}$, and $\mathrm{cc}$ which are involved in hemolytic disease of the newborn. The antibodies active in this system are probably of $\operatorname{IgG}$ class. (2) The sera of sensitized mothers and cord blood contain antibodies active in the ADCMC test. (3) There was some overall correlation between the severity of the hemolytic disease and the percentage of lysis induced in the direct ADCMC assay. Further work is needed, performed at various effector cell to targe cell ratios, to provide better information in this regard and to compare the prognostic values of either the direct Coombs' test or the direct ADCMC assay. (4) Effector cells are present in the newborn circulation.

\section{SUMMARY}

Antibody-dependent monocyte-mediated cytotoxicity can destroy fetal erythrocytes. All of the components necessary for this destruction are present in newborn infants with fetal-maternal incompatibility.

\section{REFERENCES AND NOTES}

1. Abramson, N., Gelfand, E. W., Jandl, J. H., and Rosen, F. S.: The interaction between human monocytes and red cells. Specificity for IgG subclasses and IgG fragments. J. Exp. Med., 132: 1207 (1970)

2. Abramson, N., LoBuglio, A., Jandl, J., and Cotran, R.: The interaction between human monocytes and red cells. Binding characteristics. J. Exp. Med., 132: $1192(1970)$.

3. Abt, A. F.: Mononuclear erythrophagocytosis in the blood of a newborn infant. Amer. J. Child., 42: 1364 (1931).

4. Archer, G. T.: Phagocytosis by human monocytes of red cells coated with Rh antibodies. V.ox Sang, 10: 590 (1965).

5. Dacie, J. V.: Autoimmune haemolytic anaemias. Brit. Med. J. 2: 381 (1970).

6. Fahey, J. L., and McKelvely, E. M.: Quantitative determination of serum immunoglobulines in antibody-agar plates. J. Immunol., 94: 84 (1965).

7. Holm, G.: Lysis of antibody treated human erythrocytes by human leukocytes 
and macrophages in tissue culture. Int. Arch. Allergy, 43: 671 (1972).

8. Holm, G., Engwall, E., Hammarström, S., and Natvig, J. B.: Antibody-induced hemolytic activity of human blood monocytes. The role of antibody class and subclass. Scand. J. Immunol., 2: 173 (1974).

9. Holm, G., and Hammarström, S.: Haemolytic activity of human blood monocytes. Lysis of human erythrocytes treated with anti-A serum. Clin. Exp. Immunol., 13: 29 (1973).

10. Huber, H., Douglas, S. D., and Fudenberg, H. H.: The IgG receptor: An immunological marker for the characterization of mononuclear cells. Immunology, 17: 7 (1969).

11. Huber, H., and Fudenberg, H. H.: Receptor sites of human monocytes for IgG. Int. Arch. Allergy, 34: 18 (1968).

12. LoBuglio, A. F., Cotran, R. S., and Jandl, J. H.: Red cells coated with immunoglobulin $\mathrm{G}$ : Binding and sphering by mononuclear cells in man. Science, 158: 1582 (1967).

13. MacDonald, H. R., Bonnard, G. D., Sordat, B., and Zawodnik, S. A.: Antibody-dependent cell-mediated cytotoxicity: Heterogeneity of effector cells in human peripheral blood. Scand. J. Immunol., 4: 487 (1975).

14. Mancini, G., Carbonara, A. O., and Heremand, J. F.: Immunochemical quantitation of antigens by single radial immunodiffusion. Immunochemistry, 2: 235 (1965)

15. Trinchieri, G., Baumann, P., De Marchi, M., and Tökés, Z.: Antibody-dependen cell-mediated cytotoxicity in human: I. Characterization of the effector cell. J. Immunol., 115: 249 (1975).
16. Gibco, Grand Island, N. Y

17. Kindly provided by our local Red Cross Blood Transfusion Center.

18. Institut fur Reactorforschung, Würenlingen, Switzerland.

19. Division American Hospital Supply Corporation, Miami, Fla

20. Milian Instruments, Geneva, Switzerland.

21. Nuclear-Chicago, Chicago, Ill.

22. Informed consent was obtained from the children's mothers before all testing was done.

23. We are much indebted to Dr. B. de Wuilleret and to Mrs. C. Boumghar-Cachin (Red Cross Blood Transfusion Center, Lausanne) for providing excellent advice and assistance during this work. We are grateful to Dr. A. C. Campbell for his assistance in the preparation of this manuscript.

24. The present address of Dr. H. R, MacDonald is: Radiobiology Section, Ontario Cancer Foundation, Victoria Hospital, London, Ontario NGA 4G5 (Canada).

25. The present address of Dr. G. D. Bonnard is: Laboratory of Immunodiagnosis, National Cancer Institute, Bethesda, Md. 20014 (USA).

26. This work was supported by grants of the Swiss National Foundation for Scientific Research. Dr. H. R. MacDonald was supported by a postdoctoral fellowship from the Medical Research Council of Canada and Dr. G. D. Bonnard in part by the Foundation of the Swiss Academy of Medicine.

27. Requests for reprints should be addressed to: S. A Zawodnik, M.D. Immunogenetic Laboratory, Department of Pediatrics, Hôpital Cantonal Universitaire, 1011 Lausanne (Switzerland).

28. Accepted for publication Arpil 1, 1976
Adenosine triphosphate hemoglobin synthesis erythroblasts fetus hypoxia

liver

\title{
Effect of Hypoxia on Erythroblasts from Avian Fetal Liver: Adenosine Triphosphate Levels and Hemoglobin Synthesis
}

\author{
A. L. SCHWARTZ, R. SCHWARTZ, AND H. C. SCHWARTZ \\ Department of Pharmacology, Case Western Reserve University School of Medicine, Cleveland, Ohio; Section on \\ Reproductive and Developmental Medicine, Brown University Program in Medicine and the Department of \\ Pediatrics, Rhode Island Hospital, Providence, Rhode Island; Section of Developmental Medicine, \\ Department of Pediatrics, Stanford University School of Medicine, Stanford, California, USA
}

\section{Extract}

A system for the isolation and functional evaluation of fetal liver erythroblasts is described. Isolated erythroblasts were prepared from 14-day embryonic avian livers and incubated at various oxygen tensions $(0,5,12$, and $95 \%)$. The concentration of ATP in erythroblasts remained constant for at least $4 \mathrm{hr}$ at $37^{\circ}$, but was rapidly reduced by incubation in nitrogen. Protein synthesis as measured by $\mathrm{L}-\left[{ }^{14} \mathrm{C}\right]$ leucine incorporation into cell protein occurred at a linear rate in $5 \%, 12 \%$, and $95 \%$ oxygen, whereas little protein synthesis occurred at $0 \%$ oxygen. The effect of hypoxia on the type of hemoglobin synthesized was studied in this system by isolating the hemoglobin $\mathrm{A}$, hemoglobin $\mathrm{D}$, and hemoglobin $H$ fractions and determining the incorporation of $\mathrm{L}-\left[{ }^{1} \mathrm{C}\right]$ leucine. The major fraction, hemoglobin $\mathrm{A}$, contained most of the radioactivity; smaller amounts were present in hemoglobin $D$ and hemoglobin $H$, respectively. The relative proportion of each hemoglobin synthesized was not altered by oxygen from $5 \%$ to
95\%. These results argue against a direct effect of oxygen on the type of hemoglobin synthesized at this stage of development.

\section{Speculation}

Early in fetal development nonerythropoietin mechanisms for the regulation of erythropoiesis may exist. The hypoxic stimulus to erythropoiesis is mediated through erythropoietin in definitive erythroblasts, but may have a direct effect in primitive erythroblasts.

A major step towards therapy for sickle cell anemia and the thalassemia syndromes, the most common of the hereditary hemolytic anemias, would be an understanding of erythropoiesis during development. In man the pattern is probably like that in the avian embryo, where erythropoiesis develops from a primitive to a definitive cell with associated changes from embryonic to adult hemoglobins $(11,12,14,22,36,43)$. A similar developmen- 